\title{
Hydrocarbon gases associated with alkaline igneous activity: evidence from compositions of fluid inclusions
}

\author{
Jens Konnerup-Madsen, John Rose-Hansen and Elfinn Larsen
}

The importance of volatile components in the generation and crystallization of alkaline rocks has been emphasized by a number of authors (see review by Kogarko, 1974). One method of determining the character of the volatile components associated with natural magmatism is to study the volatiles trapped as fluid inclusions in minerals during formation of the rocks. Although there may often be difficulties in relating the volatiles observed in fluid inclusions in minerals to those present in the melt at the time of solidification, this approach is considered to provide a potential method for determining the characteristics of volatiles associated with formation of natural rocks.

Studies of fluid inclusions in minerals and rocks from various alkaline complexes have shown the presence of considerable amounts of hydrocarbon gases together with highly alkaline aqueous fluids (Petersilie \& Sørensen, 1970; Sobolev et al., 1974). The relation between these two contrasting types of fluids is still somewhat uncertain. Microscopic observations, however, suggest that the hydrocarbon gases were entrapped in the minerals by preferential enclosure of immiscible droplets of hydrocarbons within a saline aqueous fluid (Konnerup-Madsen et al., 1979).

\section{Gases in the llímaussaq intrusion}

Analyses of the gases in fluid inclusions in Ilímaussaq minerals and whole rocks show them to be composed predominantly of hydrocarbons (especially $\mathrm{CH}_{4}$ ), varying amounts of hydrogen, and minor amounts of $\mathrm{He}, \mathrm{CO}_{2}$ and/or $\mathrm{CO}$ (Petersilie \& Sørensen, 1970; Konnerup-Madsen et al., 1979). In addition, smaller amounts of $\mathrm{N}_{2}, \mathrm{Ar}$ and $\mathrm{O}_{2}$ appeared in the analyses. Sobolev et al. (1970) have described individual primary inclusions in nepheline, chkalovite and tugtupite composed predominantly of $\mathrm{CO}_{2}$ and/or $\mathrm{N}_{2}+$ inert gases.

In fig. 1 the analyses from Konnerup-Madsen et al. (1979) are plotted in a triangular diagram representing $\mathrm{N}_{2}, \mathrm{O}_{2}$ and Ar. The data points fall largely along a line originating in the atmospheric composition point, thus suggesting that the observed variation is due to varying atmospheric contamination. Fig. 1 further suggests that the original (uncorrected) gas analyses represent a mixture of air and an oxygen free gas with a $\mathrm{N}_{2} / \mathrm{Ar}$ ratio of about 32 . In Table 1 the $\mathrm{N}_{2}$ and Ar have been corrected for air contamination by subtracting amounts corresponding to the $\mathrm{O}_{2}$ contents (Giggenbach \& Le Guern, 1976).

The He appearing in the gas analyses in Table 1 may both represent the He initially trapped in fluid inclusions and crystal imperfections during growth of the minerals, and the He deposited in the crystal structure by radioactive decay after crystallization. The contribution from radioactive decay can be calculated from the age of the Ilímaussaq intrusion and 


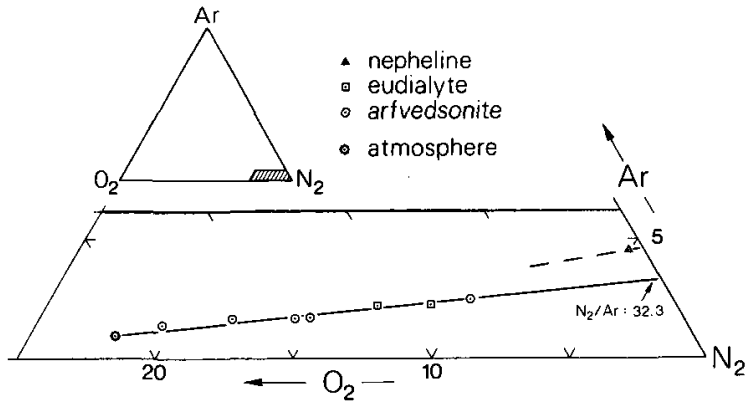

Fig. 1. Relative $\mathrm{N}_{2}, \mathrm{O}_{2}$ and Ar contents of gases released from minerals from naujaite and sodalite foyaite from the Ilímaussaq intrusion. Data from Konnerup-Madsen et al. (1979).

the present mineral and whole rock contents of $U$ and Th. In naujaite this contribution averages $1.7 \mu \mathrm{l} \mathrm{He} / \mathrm{g}$ which is slightly higher than the amount obtained by ball-mill crushing of naujaite (about $1.2 \mu \mathrm{l} \mathrm{He} / \mathrm{g}$ ). In order to examine whether these low He yields could be due to ineffective opening of fluid inclusions during ball-mill crushing a series of determinations of the He liberated on heating to $900^{\circ} \mathrm{C}$ were performed. These experiments indicated that the amount of $\mathrm{He}$ liberated on heating was up to 4 times the amount obtained on ball-mill crushing. Three examples of the He release pattern on heating are shown in fig. 2 .

The amount of He determined on heating does however not only indicate the He liberated from burst inclusions but probably also $\mathrm{He}$ evolved directly from the crystal lattice. The latter contribution may be estimated from the difference between the amount determined by heating and by ball-mill crushing as the latter method probably provides a maximum estimate of the He content in the fluid inclusions (Piperov \& Penchev, 1973). Such an estimate may

Table 1. Chemical composition of gases released by ball-mill crushing in vacuum of minerals from the Ilimaussaq intrusion

\begin{tabular}{|c|c|c|c|c|c|c|c|c|c|c|c|c|c|c|c|c|}
\hline Mineral & & $\begin{array}{l}\text { lock type } \\
\text { and } \\
\text { mple no. }\end{array}$ & $\begin{array}{c}\text { Total gas } \\
\text { volume } \\
\mathrm{CC} / \mathrm{G}\end{array}$ & $\mathrm{N}_{2}$ & Ar & $\mathrm{CO}_{2}$ & $\mathrm{He}$ & $\mathrm{H}_{2}$ & $\mathrm{CH}_{4}$ & $\mathrm{C}_{2} \mathrm{H}_{6}$ & $\mathrm{C}_{3} \mathrm{H}_{8}$ & $\stackrel{i}{\mathrm{C}_{4} \mathrm{H}_{10}}$ & $\mathrm{C}_{4}{ }^{\mathrm{n}}{ }_{10}$ & $\mathrm{C}_{5} \mathrm{i}_{12}^{\mathrm{i}}$ & $\stackrel{n}{C_{5} H_{12}}$ & other \\
\hline \multirow[t]{3}{*}{ Sodalite } & $\mathbf{N}$ & 154331 & 1.03 & 7.3 & & 0.4 & 0.01 & 4.2 & 76.1 & 9.2 & 1.9 & 0.2 & 0.61 & & & \\
\hline & & $=154350$ & 0.12 & 13.0 & & 4.0 & 0.04 & 3.5 & 70.0 & 7.3 & 1.1 & 0.14 & 0.28 & & 0.07 & \\
\hline & SF & $=154351$ & 0.06 & & & & 0.58 & 19.7 & 68.4 & 9.5 & 1.2 & 0.15 & 0.41 & & & \\
\hline Nepheline & $\mathbf{N}$ & 154331 & 0.48 & 3.5 & 0.15 & 0.4 & 0.04 & $\cdot 6.3$ & 80.7 & 8.6 & 1.1 & 0.13 & 0.26 & 0.11 & 0.03 & 0.09 \\
\hline \multirow[t]{5}{*}{ Arfvedsonite } & $\mathbf{N}$ & 1.54331 & 0.17 & 2.5 & 0.14 & 1.0 & 0.16 & 10.7 & 74.2 & 9.1 & 1.3 & & & & & \\
\hline & $\mathbf{N}$ & 57041 & 0.17 & 2.4 & 0.14 & 0.21 & 1.05 & 16.4 & 75.6 & 4.5 & 0.4 & 0.03 & 0.05 & 0.016 & 0.006 & \\
\hline & $\mathbf{N}$ & 154309 & 0.19 & 4.3 & 0.14 & 0.54 & 0.52 & 24.9 & 61.7 & 6.1 & 0.8 & 0.08 & 0.18 & 0.051 & 0.019 & \\
\hline & SF & $F 154350$ & 0.03 & 7.9 & 0.31 & 0.52 & 2.29 & 11.5 & 66.9 & 7.8 & 1.3 & 0.08 & 0.78 & 0.042 & 0.021 & \\
\hline & SF & $=154351$ & 0.02 & 8.4 & 0.37 & 1.31 & 3.68 & 30.2 & 51.2 & 3.7 & 0.4 & 0.04 & 0.08 & 0.018 & 0.011 & \\
\hline \multirow[t]{2}{*}{ Eudialyte } & $\mathbf{N}$ & 154331 & 0.43 & 2.5 & 0.08 & 0.92 & 0.36 & 34.7 & 43.8 & 13.3 & 2.0 & 0.19 & 0.5 & 0.153 & 0.061 & 0.051 \\
\hline & $N$ & 57041 & 0.14 & 4.5 & 0.17 & 1.36 & 0.52 & 16.8 & 51.4 & 18.9 & 4.2 & 0.24 & 0.8 & 0.283 & 0.178 & 0.126 \\
\hline Chkalovite & & $\dagger$ & 0.13 & 2.1 & 0.03 & $\operatorname{tr}$ & 1.9 & 44.0 & 51.5 & & & & & & & \\
\hline
\end{tabular}

\footnotetext{
* The gases are measured at $760 \mathrm{~mm} \mathrm{Hg}$ and $0^{\circ} \mathrm{C}$. The values indicate the total amount of gas released mmus water in relation to the fraction of crushed material less than $10 \mu \mathrm{m}$ grain size.

$\uparrow$ Chkalovite from an ussingite vein north of Taseq.

N: Naujaite SF: Sodalite foyaite
}

Analyses corrected from Konnerup-Madsen et al. (1979) as described in text. The analyses are expressed as volume percentages and are given on $\mathrm{a}_{2} \mathrm{O}$-free basis. 
Fig. 2. (A) Amounts of He released on heating as function of temperature. Amounts expressed as percentages of the total amount liberated (in $\mu \mathrm{l} \mathrm{He/g} \mathrm{mineral)} \mathrm{given}$ in parentheses in the figure. (B) Differential curves of the He release on heating. Curves based on (A).

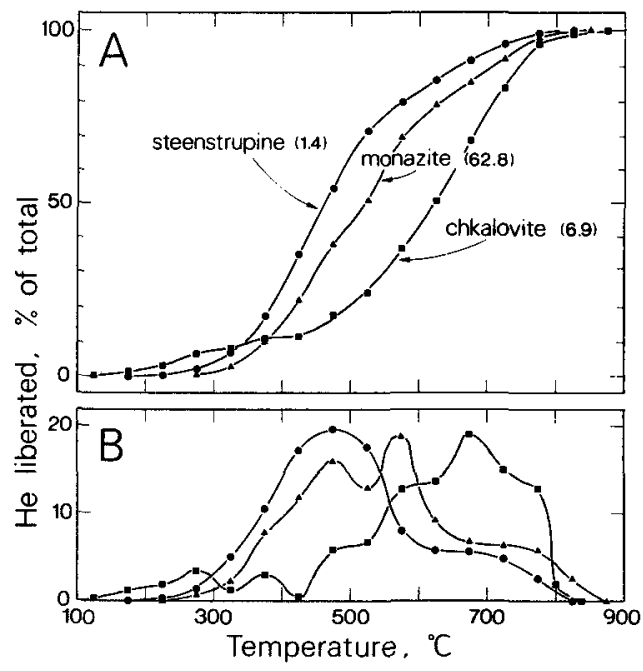

be made for chkalovite where the amount of He liberated on heating to $900^{\circ} \mathrm{C}(6.9 \mu \mathrm{l} \mathrm{He} / \mathrm{g}$; fig. 2) is $4.4 \mu \mathrm{l} \mathrm{He} / \mathrm{g}$ higher than the amount liberated on ball-mill crushing $(2.5 \mu \mathrm{l} \mathrm{He} / \mathrm{g}$; Table 1). As the content of radioactive elements in chkalovite is extremely low ( $1 \mathrm{ppm}$ ) a $\mathrm{He}$ addition from radioactive decay may tentatively be ignored and the He obtained thus related to the He present during crystallization of the chkalovite. However, the multiplicity of origins and possible sites of $\mathrm{He}$ in the minerals and rocks makes an interpretation somewhat ambiguous at present.

\section{Chemical equilibrium of the Ilímaussaq gas phase}

Chemical equilibria of components of volcanic gas samples have often been inferred, although supporting evidence from thermodynamic considerations is scarce (Gerlach \& Nordlie, 1975). Considering analyses of gases released from fluid inclusions, an additional problem arises from the fact that an analysis generally represents a mixture of the gases released from not only several generations of inclusions (probably of different chemistry) but also from various other sites in the minerals and rocks (Barker, 1974). Analyses such as those in Table 1 thus represent 'average' compositions, and any calculation of possible equilibrium conditions involves the premise that one generation of trapped gases predominates in the analyses.

A commonly used method for such calculations consists in relating analytically obtained concentrations of gases to thermodynamic equilibrium constants of selected, pertinent reactions. Following this approach calculations of possible $\left(\log \mathrm{O}_{2}, T\right)$-equilibrium conditions for the llímaussaq gases (Table 1) have been attempted on the basis of some reactions involving a $\mathrm{C}-\mathrm{H}-\mathrm{O}$ gas phase in equilibrium with graphite, relating to the compounds $\mathrm{H}_{2}, \mathrm{H}_{2} \mathrm{O}, \mathrm{CH}_{4}$, $\mathrm{CO}_{2}$ and $\mathrm{O}_{2}$ and assuming that these together exert almost the total pressure of the gas phase. Deviations from this ideal model concept mainly stem from observations that significant contents of higher hydrocarbons are present in the gas phase, and that some additional 
part of the gas phase probably is composed of phases within a larger system (e.g., involving $\mathrm{Cl}$ and/or $\mathrm{F}$, and $\mathrm{N}$ ). The presence of bituminous substances in the rocks (Petersilie \& Sørensen, 1970) has also been ignored. With these limitations calculations of possible (log $\mathrm{fo}_{2}, T$ )-equilibrium conditions have been done on the basis of the reactions:

(1) $\mathrm{H}_{2}+1 / 2 \mathrm{O}_{2}=\mathrm{H}_{2} \mathrm{O}$;

(2) $\mathrm{C}+\mathrm{O}_{2}=\mathrm{CO}_{2}$

$$
K_{T, P}(1)=\left[X_{\mathrm{H}_{2} \mathrm{O}} / X_{\mathrm{H}_{2}} \cdot\left(f_{\mathrm{O}_{2}}\right)^{1 / 2}\right] \cdot \gamma_{\mathrm{H}_{2} \mathrm{O}} / \gamma_{\mathrm{H}_{2}}
$$

$K_{T, P}(2)=\left[X_{\mathrm{CO}_{2}} / f_{\mathrm{O}_{2}}\right] \cdot \gamma_{\mathrm{CO}_{2}}$

and

(4) $P_{\mathrm{gas}}=P_{\mathrm{H}_{2}}+P_{\mathrm{H}_{2} \mathrm{O}}+P_{\mathrm{CH}_{4}}+P_{\mathrm{CO}_{2}}+P_{\mathrm{O}_{2}}$

where $X_{\mathrm{i}}$ and $\gamma_{\mathrm{i}}$ denote mole fraction and fugacity coefficient of component $\mathrm{i}$, respectively. The thermodynamic data $\left(K_{T, P}\right.$ and $\left.\gamma_{\mathrm{i}}\right)$ relating to the above reactions have been taken from Ohmoto (1968), Skippen (1971) and Cusumano et al. (1978). Reactions (1)-(4) permit calculation of $\log \mathrm{fo}_{2}$ as a function of temperature using the analytically obtained values for $\mathrm{H}_{2}, \mathrm{CH}_{4}$ and $\mathrm{CO}_{2}$ (Table 1) and specifying $P_{\text {gas }}$ and $P_{\mathrm{H}_{2}} \mathrm{O}$. Calculations were performed on the assumption of ideal mixing of gases. The resulting $\left(\log f o_{2}, T\right)$-conditions of possible equilibrium of gases are shown in fig. 3B.

The calculations involve estimates of both the total gas pressure and the mole fraction of water $\left(P_{\mathrm{H}_{2}} \mathrm{O}\right)$ in the gas phase.

$P_{\text {gas }}$. A value of 1000 bars for the gas pressure $\left(=P_{\text {total }}\right)$ has been used in the calculations. This value was chosen because selected homogenization data for both aqueous and hydrocarbon-rich inclusions in minerals from the Ilimaussaq intrusion suggest entrapment of gases at pressures between 1.4 and $0.8 \mathrm{~kb}$ at maximum temperatures from $800^{\circ}$ down to $500^{\circ} \mathrm{C}$ (Konnerup-Madsen et al., 1979). Similar values were inferred by Sørensen (1968) and Lar$\operatorname{sen}(1976)$.

$P_{\mathrm{H}_{2}} \mathrm{O}$. The value of $\mathrm{P}_{\mathrm{H}_{2}} \mathrm{O}$ can only be semi-quantitatively ascertained. The water-free character of the mafic liquidus minerals and the largely intercumulus crystallization stage of hydrous mafic minerals in the naujaite and the sodalite foyaite (Larsen, 1976) indicate that the main magma initially was water-deficient. On the basis of petrographic observations coupled with experimental studies on similar rock types from the Lovozero intrusion, Kogarko \& Romanchev (1978) arrived at an estimate of the water pressure of 100 to 200 bars during the initial stages of crystallization of the Lovozero rocks. The results of calculations presented in fig. 3B were obtained with a $P_{\mathrm{H}_{2} \mathrm{O}}$ of 500 bars. The effect of increasing/lowering the water pressure by 250 bars, however, only produces a slight shift in the $\log \mathrm{fo}_{2}$ values (by about $1 \log$-unit) toward higher/lower values.

The range in $\left(\log f \mathrm{O}_{2}, T\right)$-conditions of possible equilibration of gases shown in fig. $3 \mathrm{~B}$ is in accordance with estimates based on mafic minerals in these rocks (Larsen, 1976) and oxides from hydrothermal veins (Karup-Møller, 1978). The gases could well have been in equilibrium with graphite over a rather extensive temperature range. In fig. $3 \mathrm{~A}$ comparison can be made with the sequence of crystallization of the main minerals in the Ilímaussaq roof rocks (Larsen, 1976), with tentatively imposed temperatures based on Piotrowski \& Edgar (1970) and Larsen (1977).

The results obtained on the Ilímaussaq gases (fig. 3B) further agree with those obtained on the Lovozero intrusion where oxygen fugacities below those of the QFM buffer reaction 
Fig. 3. (A) Sequence of crystallization of minerals in llimaussaq roof rocks. Based on data from Piotrowski \& Edgar (1970) and Larsen (1976, 1977). Estimated trapping of hydrocarbons from KonnerupMadsen et al. (1979). Abbreviations: Ac (acmite), Acg (acgirine), Aen (aenigmatite), Arf (arfvedsonite), Astr (astrophyllite), Fa (fayalite), Hed (hedenbergitc), Kat (kataphorite), Mgt (magnetite), Nept (neptunite). (B) Calculated $\left(\log f \mathrm{o}_{2}, T\right)$-conditions for possible equilibration of Ilímaussaq gases at $P_{\text {total }}=1000$ bars as described in text. Data for late hydrothermal veins in Ilímaussaq from Karup-Møller (1978).

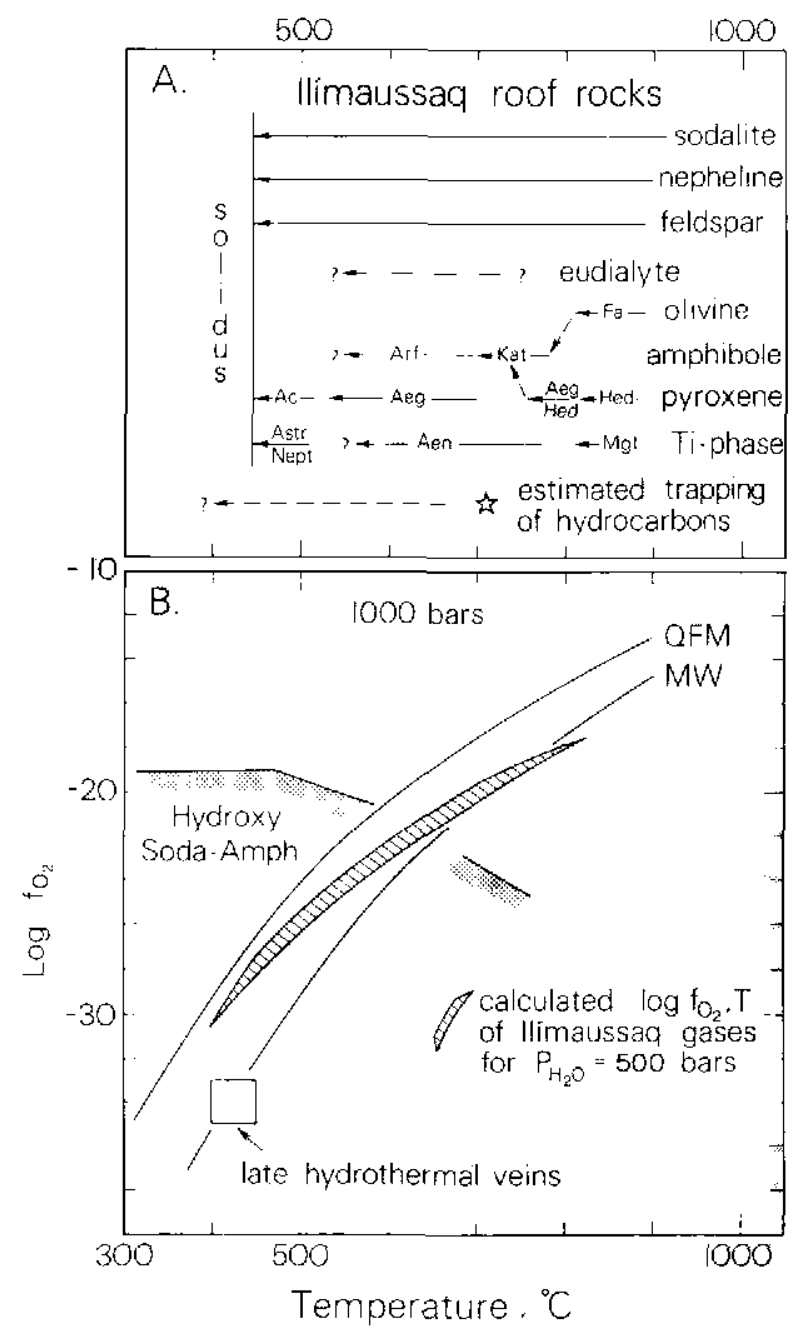

have been inferred (Kogarko, 1972). Kogarko \& Romanchev (1978) arrived at estimated partial pressures of $\mathrm{CH}_{4}$ in the order of 500 to 700 bars during the later stages of crystallization of the Lovozero rocks. Very similar results can be obtained for the Ilímaussaq intrusion (Table 1).

\section{Comparison of the Ilímaussaq gases with those of other alkaline complexes and various magmatic rocks}

The chemical characteristics of gases from minerals and rocks from various alkaline complexes have been presented on a $\mathrm{H}_{2} \mathrm{O}$-free basis in figs. 4 to 6 . In fig. 4 the relative proportions of helium, hydrogen and the hydrocarbons, and in fig. 5 the chemical composition in terms of atomic $\mathrm{C}-\mathrm{O}-\mathrm{H}$ proportions of gases from minerals and agpaitic rocks from the 


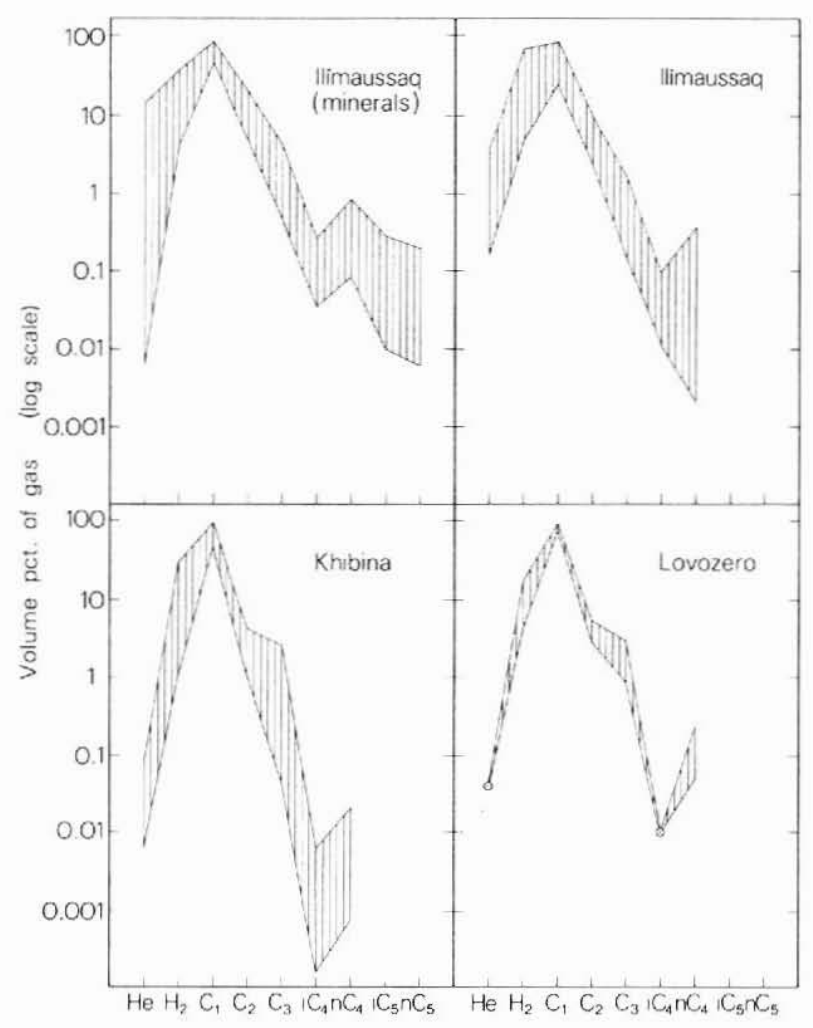

Fig. 4. Volume percentages of $\mathrm{He}, \mathrm{H}_{2}$ and hydrocarbons (given as $\left.\mathrm{C}_{\mathrm{i}}: \mathrm{C}_{\mathrm{i}} \mathrm{H}_{2 \mathrm{i}}+2\right)$ in gases released from minerals and agpaitic rocks from the alkaline intrusions Ilímaussaq, Khibina and Lovozero. Based on analyses from Petersilie (1963), Petersilie \& Sørensen (1970), Roedder (1972) and Table 1 (this paper).

Ilímaussaq intrusion have been compared with those of agpaitic rock types from the alkaline Khibina and Lovozero complexes of the Kola Peninsula (USSR). The pronounced similarity of gases from these three complexes suggests that analogous processes and conditions of formation are responsible for the observed characters of the volatile phase. The volatile phase was in a very reduced state, with oxygen fugacity values below those given by the QFM buffer reaction (fig. 3B), during formation of the rocks. A catalytic effect of the minerals and rocks in these complexes (Bashkirov et al., 1956; Cusumano et al., 1978) may possibly account for the formation of the relatively high amounts of higher hydrocarbons (e.g., Table 1).

The chemical $\mathrm{C}-\mathrm{O}-\mathrm{H}$ proportions of the gases released from minerals and rocks from various alkaline complexes have been collected in fig. 6 . The large spread in compositions that can be observed is probably in part due to the plotting in the same diagram of analyses of gases from a variety of rock types representing different evolutionary stages. The scatter, however, to a certain extent represents the grouping into complexes with a gas phase composed mainly of $\mathrm{CH}_{4}+\mathrm{CO}_{2} / \mathrm{CO}$ (fig. 6; open symbols) and complexes with a gas phase mainly composed of $\mathrm{H}_{2}+\mathrm{CO}_{2} / \mathrm{CO}$ (fig. 6 ; closed symbols). A similar division was made by Petersilie \& Sørensen (1970) for gases from the Ilímaussaq intrusion where a group with hydrogen predominating could be distinguished from one where hydrocarbons (especially $\mathrm{CH}_{4}$ ) dominated. 


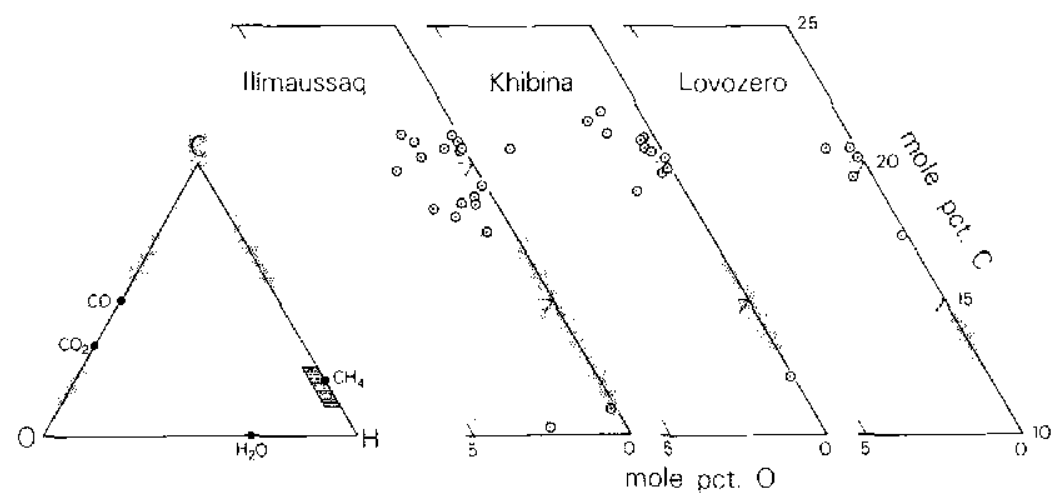

Fig. 5. C.O-H molecular relations for gases released by crushing of minerals and agpaitic rock types from the Ilimaussaq, Khibina and Lovozero intrusions. Recalculated on a water-free basis. Source of data as for fig. 4.

The composition of gases quoted as typical of alkaline effusive rocks (Soboley et al., 1972; Bazarova et al., 1973) resembles in some respect the $\mathrm{H}_{2}+\mathrm{CO}_{2} / \mathrm{CO}$ group of gases (fig. 6) but is much richer in $\mathrm{CO}_{2}$. Kogarko \& Romanchev (1978) considered this type to be typical for the magmatic gases associated with alkaline magmatism. The gases generally observed in minerals and rocks from alkaline complexes might conceivably be related to these higher temperature gases through reactions such as

and

$$
\mathrm{CO}+3 \mathrm{H}_{2}=\mathrm{H}_{2} \mathrm{O}+\mathrm{CH}_{4}
$$

$$
\mathrm{CO}_{2}+4 \mathrm{H}_{2}=2 \mathrm{H}_{2} \mathrm{O}+\mathrm{CH}_{4}
$$

A comparison of the gases from the Ilimaussaq intrusion with those from fluid inclusions from various non-alkaline magmatic rock types is shown in fig. 7 . In terms of the C-O-H proportions gases from the Ilimaussaq intrusion plot distinctly different from those of other rock types. Gases from Ilímaussaq fall largely in the compositional field defined by $\mathrm{CO}, \mathrm{H}_{2}$ and $\mathrm{CH}_{4}$, whereas gases from the various non-alkaline rock types shown plot within the field defined by $\mathrm{CO}_{2}, \mathrm{CO}$ and $\mathrm{H}_{2} \mathrm{O}$ (fig. 7).

Fig. 6. C-O-H molecular relations for gases in minerals and rocks from various alkaline complexcs. Based on analyses from Petersilie et al. (1965), Ikorskii (1967), those from fig. 4, and unpublished analyses from the Igaliko intrusion (GGU 58222, South Qoroq Center, Unit SS5 (Emeleus \& Harry, 1970)). $\mathrm{H}_{2} \mathrm{O}$ is not included in the analyses.

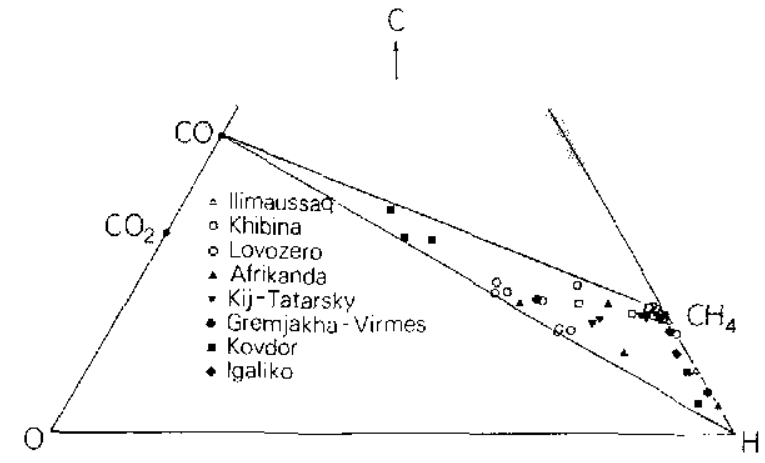




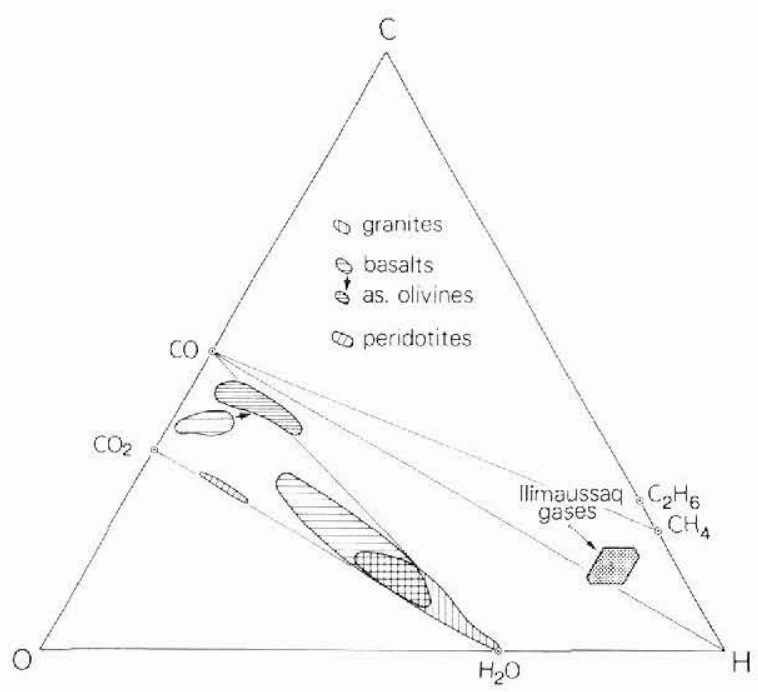

Fig. 7. $\mathrm{C}-\mathrm{O}-\mathrm{H}$ molecular relations for gases in minerals and rocks from various non-alkaline magmatic rock types compared to gases from agpaitic nepheline syenites from Ilímaussaq. $\mathrm{H}_{2} \mathrm{O}$ included in the analyses. Based on analyses from Chemla et al. (1968), Roedder (1972), Barker \& Sommer (1973), and Chaigneau (1975).

Gases from alkaline and non-alkaline rock types have finally been compared on a $\mathrm{H}_{2} \mathrm{O}$ free basis in a triangular diagram representing $\mathrm{H}_{2}, \mathrm{CO}_{2}+\mathrm{CO}$, and total hydrocarbons (fig. 8). Gases from non-alkaline magmatic rock types consist mainly of $\mathrm{CO}_{2}+\mathrm{CO}$ with varying amounts of $\mathrm{H}_{2}$, whereas gases from the various alkaline complexes are distinct in having high contents of hydrocarbons and minor variable $\mathrm{H}_{2}$ and/or $\mathrm{CO}_{2}+\mathrm{CO}$ contents.

\section{Concluding remarks}

The data presented in the preceeding paragraphs indicate that the characteristic vapour phase associated with alkaline magmatic activity in the later stages of solidification of these

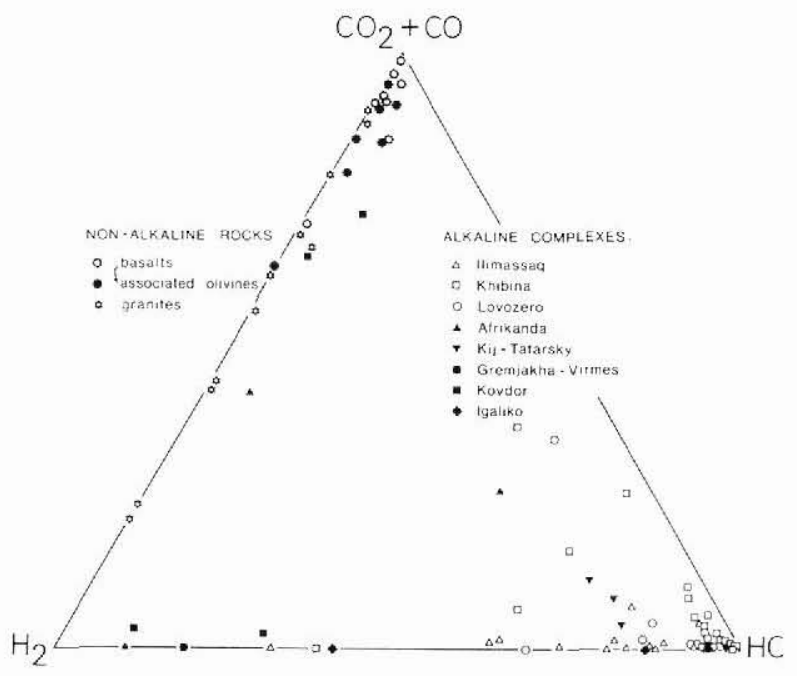

Fig. 8. Relative $\mathrm{H}_{2}, \mathrm{CO}_{2}+\mathrm{CO}$ and total hydrocarbon contents of gases from various alkaline and non-alkaline rock types. Source of data as for previous figures. 
rocks is rich in reduced gases such as $\mathrm{CH}_{4}$ and/or $\mathrm{H}_{2}$, and deficient in $\mathrm{H}_{2} \mathrm{O}$. This is in marked contrast to gases associated with most other rock types that are characterized by high contents of $\mathrm{H}_{2} \mathrm{O}$ and $\mathrm{CO}_{2}+\mathrm{CO}$, and with subordinate amounts of $\mathrm{CH}_{4}$ and $\mathrm{H}_{2}$.

Even with very low initial water contents of melts the presence of $\mathrm{CO}_{2}$ and/or $\mathrm{CH}_{4}$ will create a free vapour phase even though there is insufficient water to alone saturate the melt under the given conditions. The evolution and existence of such a hydrocarbon-rich, $\mathrm{H}_{2} \mathrm{O}$-, Cl-bearing fluid phase could well influence certain trace elements (e.g. REE; Collerson \& Fryer, 1978) and isotope distribution patterns during crystallization of the Ilímaussaq and other alkaline rocks.

Acknowledgements. The financial support provided by the Danish Natural Science Research Council (J.nr. 511-8078 \& 511-10120) for one of us (J. K.-M.) during this work is gratefully acknowledged. The manuscript has benefited from discussion and criticism by J. C. Bailey, L. M. Larsen and H. Sørensen.

\section{References}

Barker, C. 1974: Composition of the gases associated with the magmas that produced rocks 15016 and 15065. Geochim. cosmochim. Acta 2 (Suppl. 5), 1737-1746.

Barker, C. \& Sommer, M. A. 1973: Mass spectrometric analysis of the volatiles released by heating or crushing rocks. Analytical Methods Developed for Application to Lunar Samples Analyses. American Soc. for Testing and Materials STP 539, 56-70.

Bashkirov, A. N., Loktev, S. M. \& Kamzolkin, V. V. 1956: On the catalytic activity of some silicate minerals in the synthesis of hydrocarbons from carbon oxides and hydrogen (in Russian). Khimiga Tekhnol. Topl. 3, 38-42.

Bazarova, T. Yu., Canilho, E. M., Sobolev, V. S. \& Shugurova, N. A. 1973: Temperatures and conditions of crystallization of alkaline effusives from the Majo Isle (Cap Vert). Lithos 6, 403-411.

Chaigneau, M. 1975: Essai sur la composition des gaz magmatiques profonds. Bull. volcanol. 39, 1-13.

Chemla, M., Touray, J. C., Brousse, R. \& Causse, C. 1968: Abondance relative des gaz inclus dans quelques minéraux magmatiques d'origine profonde. In L. H. Ahrens (edit.) Origin and distribution of the elements, 971-979. London: Pergamon Press.

Collerson, K. D. \& Fryer, B. J. 1978: The role of fluids in the formation and subsequent development of early continental crust. Contrib. Mineral. Petrol. 67, 151-167.

Cusumano, J. A., Dalla Betta, R. A. \& Levy, R. B. 1978: Catalysis in coal conversion. New York: Academic Press, 277 pp.

Emeleus, C. H. \& Harry, W. T. 1970: The Igaliko nepheline syenite complex. Bull. Grønlands geol. Unders. 85 (also Meddr Grønland 186,3) 116 pp.

Gerlach, T. M. \& Nordlie, B. E. 1975: The C-O-H-S gaseous system, Part I: Composition limits and trends in basaltic gases. Amer. J. Sci. 275, 353-376.

Giggenbach, W. F. \& Le Guern, F. 1976: The chemistry of magmatic gases from Erta'Ale, Ethiopia. Geochim. cosmochim. Acta 40, 25-30.

Ikorskii, S. V. 1967: The organic substances in the minerals of igneous rocks (in Russian). Leningrad: Nauka, 119 pp.

Karup-Møller, S. 1978: The ore minerals of the llimaussaq intrusion: their mode of occurrence and their conditions of formation. Bull. Grønlands geol. Unders. 127, $51 \mathrm{pp}$.

Kogarko, L. N. 1972: The role of the compounds of oxygen, sulphur and carbor in magmatic gas phase of alkaline rocks. Rep. 24th Int. geol. Congr. Canada 10, 20-24.

Kogarko, L. N. 1974: Rôle of volatiles. In H. Sørensen (edit.) The alkaline rocks, 474-488. London: Wylie. 
Kogarko, L. N. \& Romanchev, B. P. 1978: Temperature, pressure, redox conditions, and mineral equilibria in agpaitic nepheline syenites and apatite-nepheline rocks. Geochemistry int. 14, 113-128.

Konnerup-Madsen, J., Larsen, E. \& Rose-Hansen, J. 1979: Hydrocarbon-rich fluid inclusions in minerals from the alkaline Ilímaussaq intrusion, South Greenland. Bull. Soc. fr. Miner. Cristallogr. 102, 642-653.

Larsen, L. M. 1976: Clinopyroxenes and coexisting mafic minerals from the alkaline Ilímaussaq intrusion, South Greenland. J. Petrol. 17, 258-290.

Larsen, L. M. 1977: Aenigmatites from the Ilímaussaq intrusion, south Greenland: Chemistry and petrological implications. Lithos 10, 257-270.

Ohmoto, H. 1968: The Bluebell mine, British Columbia, Canada: Part 2, Chemistry of the hydrothermal fluids. Unpublished $P h . D$. thesis. Princeton Univ.

Petersilie, I. A. 1963: Organic matter in igneous and metamorphic rocks of the Kola Peninsula. In A. P. Vinogradov (edit.) Chemistry of the Earth's crust, 1, 48-62. (in Russian). Moscow: Akad. Nauk. (English translation: Israel Progr. for Sci. Transl., Jerusalem, 1966).

Petersilie, I. A., Andreyeva, E. D. \& Sveshnikova, E. V. 1965: Organic substances from the rocks of certain alkali crystalline rock masses of Siberia (in Russian). Izv. Akad. Nauk, SSSR, Geol. Ser. 6, 26-38.

Petersilie, I. A. \& Sørensen, H. 1970: Hydrocarbon gases and bituminous substances in rocks from the Ilímaussaq alkaline intrusion, South Greenland. Lithos 3, 59-76.

Piotrowski, J. H. \& Edgar, A. D. 1970: Melting relations of undersaturated alkaline rocks from South Greenland. Meddr Grønland 181 (9), 62 pp.

Piperov, N. B. \& Penchev, N. P. 1973: A study of gas inclusions in minerals. Analysis of the gases from micro-inclusions in allanite. Geochim. cosmochim. Acta 37, 2075-2097.

Roedder, E. 1972: Composition of fluid inclusions. In M. Fleischer (edit.) Data of Geochemistry, U.S. Geol. Surv. Prof. Paper 440-JJ, 164 pp.

Skippen, G. B. 1971: Experimental data for reactions in siliceous marbles. J. Geol. 79, 457-481.

Sobolev, V. S., Bazarova, T. Yu. \& Bakumenko, I. T. 1972: Crystallization temperature and gas phase composition of alkaline effusives as indicated by primary melt inclusions in the phenocrysts. Bull. volcanol. 35, 479-496.

Sobolev, V. S., Bazarova, T. Yu. \& Kostyuk, V. P. 1974: Inclusions in the minerals of some types of alkaline rocks. In $\mathrm{H}$. Sørensen (edit.) The alkaline rocks, 389-401. London: Wylie.

Sobolev, V. S., Bazarova, T. Y., Shugurova, N. A., Bazarov, L. Sh., Dolgov, Yu. A. \& Sørensen, H. 1970: A preliminary examination of fluid inclusions in nepheline, sorensenite, tugtupite and chkalovite from the Ilimaussaq alkaline intrusion, South Greenland. Meddr Grønland 181 (11), 32 pp.

Sørensen, H. 1968: Rhythmic igneous layering in peralkaline intrusions. An essay review on llímaussaq (Greenland) and Lovozero (Kola, USSR). Lithos 2, 261-283.

J.K-M., J.R-H., Institut for Petrologi,

University of Copenhagen,

$\emptyset$ ster Voldgade 10,

DK-1350 Copenhagen $\mathrm{K}$.
E.L., Ris $\emptyset$ National Laboratory, 4000 Roskilde, Denmark. 